\title{
Book Review: The Study on the Entry Timing of Foreign Banks from the Perspective of Real Option
}

\author{
Xiaoyan Zhang ${ }^{1}$ \\ ${ }^{1}$ School of Business, Shandong Normal University, Jinan, 250014, China \\ Correspondence: Xiaoyan Zhang, School of Business, Shandong Normal University, No. 88 East Wenhua Road, \\ Jinan City, China. Email: breezezxy@163.com
}

Online Published: November 30, 2015

doi:10.5539/ibr.v8n12p134

URL: http://dx.doi.org/10.5539/ibr.v8n12p134

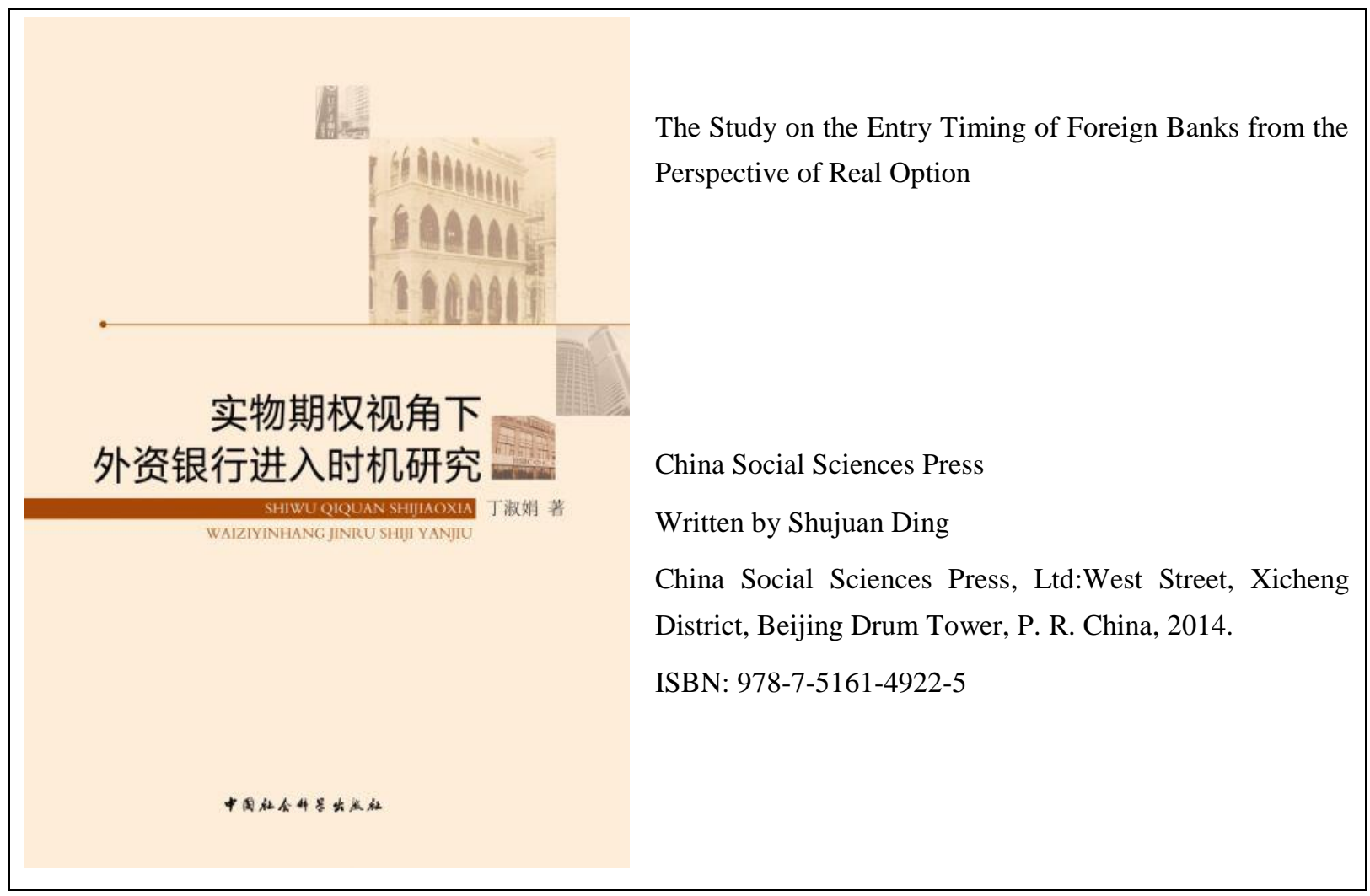

\section{Summary of Review and Endorsements}

Foreign banks have become an indispensable part of China's banking. The branches and the business are becoming more. The researches about the foreign banks have been very rich, but most of them concentrate on "Why" "How" "Where" foreign banks enter, but those about "When" are very neglected and therefore very few. But the timing (that is "when") is not the same as the motivation (that is "Why'). Even if a bank has the motivation to enter China, but the timing of entry is not certain. But only the foreign banks have entered China, it can influence China's economy. Therefore timing of entry is very important. In this book, the entry timing of foreign banks into China is studied detailed and may be helpful to the decision of foreign banks, Chinese local banks and the supervisor.

\section{Body of the Review}

In this book, "real option" is adopted to analyze foreign banks' entry timing. Real option theory can be divided into "traditional real option" and "option game". Traditional real option regards the entrant a monopolist and therefore does not consider competition. Its object is to find the best entry timing using the option pricing. 
Option game, banding real option and game theory, is to study the tactical investment of the rational entrants under an uncertain environment. The model of Dixit and Pindyck (1994) is a typical option game model. This book extends those conclusions. The typical model does not consider the first-mover advantage and dose not distinguish whether the two entrants are homogeneous or not. This book extends this model under first-mover advantage and whether homogenous.

It is feasible to study foreign banks' entry using real option, but at the same time, there is some particularity. According to real option, traditional theories about foreign banks' incentive to enter are challenged.

This book validates that, generally speaking, the incentive of foreign banks into China is "customer-following" using the method of step regression. This incentive shows that the foreign banks possess certain monopolization on their customers. Therefore the traditional real option can be used to analyze the entry timing. The reality of foreign banks' entry into China is accord with the conclusions of traditional real option but at the same time shows the characteristics of China according to the survival analysis.

However, the "local market utilization" entry motivation is becoming more and more obvious. Therefore for some foreign banks entry, option game is more perfect. Using 700 sample data, this book proves that there is "first-mover advantage" in China's banking. According to option game theory, this book analyze the situation of retail market of RMB and the rural financial market using the influential factors "first-mover advantage" "uncertainty" "present cash flow" and give some suggestions. For the supervisor, it is not sufficient only using the prudent supervision measures and restrictive measures are necessary. Under certain market environment, it may be a good choice to approve the weak bank to entry and the strong bank to wait.

Considering entry mode, the entry timing may change. Therefore this book sets up a real option mode with entry mode. "Partial Entry" is flexible and at the same time, it has some advantages over "Full Entry", such as it can obtain first-mover advantage earlier, has higher reversibility, lower transaction cost. Therefore sometimes "Partial Entry" becomes a nice choice. According to this model, for foreign banks, it is a good choice to enter China earlier by the way of shares.

Innovations of this book are as follows.

Expand Dixit and Pindyck (1994) option game model. Extend this typical model's conclusions; Reconstruct this model introducing first-mover advantage and considering whether the two enterprises are homogeneous or not.

According to the traditional real option and option game theory, using data from China's banks, this book does some empirical study. Firstly, using "step regression", this book validates that, generally speaking, the incentive of foreign banks to enter China is "customer following". Secondly, using the method of "survival analysis", this book validates that the time for foreign banks to enter China is consistent with traditional real option, but at the same, it presents its own characteristics. Thirdly, using OLS, this book validates that it is true that there is first-mover advantage in China's banking. Lastly, using option game theory, this book analyzes the situation in RMB's retail market and the rural financial market.

The analysis above is on the hypothesis that foreign banks enter fully. But the entry mode can influence the entry timing. Therefore this book constructs a real option mode with entry mode and analyzes the situation in foreign banks' entry through the way of shares.

\section{About the Book Author}

Shujuan Ding is a Vice Professor in Economic School, Shandong Normal University, P. R. China. She has a PhD Degree in Finance.

\section{Copyrights}

Copyright for this article is retained by the author(s), with first publication rights granted to the journal.

This is an open-access article distributed under the terms and conditions of the Creative Commons Attribution license (http://creativecommons.org/licenses/by/3.0/). 